\title{
As bem-aventuranças nas versões de Borges, de Machado de Assis, da Bíblia satânica de Anton Lavey e na versão ao mestre com carinho
}

\author{
Salma Ferraz
}

\section{SciELO Books / SciELO Livros / SciELO Libros}

FERRAZ, S. As bem-aventuranças nas versões de Borges, de Machado de Assis, da Bíblia satânica de Anton Lavey e na versão ao mestre com carinho. In MAGALHÃES, ACM., et al., orgs. O demoníaco na literatura [online]. Campina Grande: EDUEPB, 2012. pp. 15-46. ISBN 978-85-7879-188-9. Available from SciELO Books <http://books.scielo.org $>$.

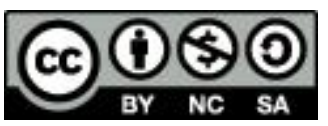

All the contents of this work, except where otherwise noted, is licensed under a Creative Commons Attribution-Non Commercial-ShareAlike 3.0 Unported.

Todo o conteúdo deste trabalho, exceto quando houver ressalva, é publicado sob a licença Creative Commons Atribuição Uso Não Comercial - Partilha nos Mesmos Termos 3.0 Não adaptada.

Todo el contenido de esta obra, excepto donde se indique lo contrario, está bajo licencia de la licencia Creative Commons Reconocimento-NoComercial-CompartirIgual 3.0 Unported. 


\title{
As bem-aventuranças nas versões de Borges, de Machado de Assis, da Bíblia satânica de Anton Lavey e na versão ao mestre com carinho
}

\author{
Salma Ferraz $(\text { UFSC })^{1}$
}

Conforme Harold Bloom em sua obra Angústia da Influência, "nenhum poeta desde Adão e Satanás fala uma linguagem livre da lavrada de seus precursores" (2002, p. 74).

Mikhail Bakhtin (1895-1975), teórico linguista russo, defende a ideia de que toda a escritura é leitura de um corpus literário anterior e entende o "texto como absorção e réplica a um outro texto..." (apud KRISTEVA, 1974, p. 67, negrito nosso), ou seja, a escritura é entendida como releitura de um corpus literário anterior. O conceito clássico de intertextualidade foi escrito por Julia Kristeva em sua obra Introdução à Semanálise:

[...] segundo a qual a palavra literária não é um ponto (um sentido fixo), mas um cruzamento de superfícies textuais, um diálogo de diversas escrituras: do escritor, do destinatário (ou da personagem), do contexto cultural atual ou anterior. [...] todo texto se constrói como mosaico de citações, todo texto é absorção e transformação de um outro texto. Em lugar da noção de subjetividade,

1 É Professora Associada de Literatura Portuguesa da Universidade Federal de Santa Catarina. Atua na Pós-graduação com a linha de Pesquisa Teopoética - Os Estudos Comparados entre Teologia e Literatura, membro da ALALITE - Associação Latino Americana de Literatura e Teologia, líder do NUTEL - Núcleo de Estudos Comparados entre Teologia e Literatura sediado na UFSC. É autora de diversos livros de teoria e ficção. Florianópolis, Brasil, 2010. E-mail: salmferraz@gmail.com. Home Page: http://teopoetica.sites.ufsc.br/salmaferraz.php 
instala-se a intertextualidade e a linguagem poética lê-se pelo menos como dupla" (1974, p. $62-64$, negrito nosso).

Os textos se relacionam entre si, como um verdadeiro mosaico de citações, um caleidoscópio, na qual textos se misturam a outros textos oriundos de mil lugares e culturas diferentes. O leitor deve ter competência para manejar esse caleidoscópio e descobrir a origem, a intersecção, a contaminação deles. O intertexto pode ocorrer por meio de epígrafes, paráfrases, citações, paródias, pastiches etc. A tradição é retomada, exaltada, relativizada e, por vezes, até negada. É isto que acontece com um dos textos bíblicos mais conhecidos do ocidente: $A s$ Bem-aventuranças.

As Bem-aventuranças proclamadas por Jesus no Sermão da Montanha e relatadas no Evangelho de Mateus 5, são, de certa forma, um espécie de contraponto aos Dez Mandamentos recebidos por Moisés no Monte Sinai, relatado no Livro do Êxodo 20:1-17. Os Dez Mandamentos foram proclamados por YHWH, um Deus tribal do panteão cananeu que com o tempo, com a história e política da reforma do Rei de Judá - Josias (639-586) - um nobre sucessor de Moisés, Josué e Davi, na versão teológica do deuteronomista, transforma-se num deus nacional. A partir de Jesus, filho de YHWH do hebraico הוהי, um judeu que viveu e atuou na periferia do poder, portanto, um judeu marginal, na feliz colocação de John P. Meier em seu livro Um Judeu Marginal, surge um movimento que incomoda os romanos, com Paulo chega a Roma e com o Cristianismo alcança o mundo. Jesus, que não conheceu a palavra Cristo

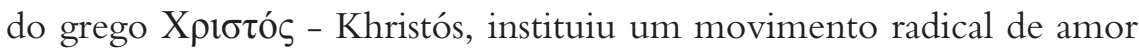
ao próximo o que poderíamos denominar de Jesuísmo. J. B. Libânio afirma que

O termo Cristianismo não se origina de Jesus, mas de Cristo. Não é o camponês e artesão Jesus que viveu na Palestina no primeiro século de nossa era que criou um movimento e o propagou pelas regiões circunvizinhas. Não nasceu um jesuanismo. [...] O Cristianismo é a forma histórica que o movimento de Jesus assumiu. (2008, p. 16) 
O autor ainda firma que o Cristianismo foi a reinterpretação do Jesus da Palestina, feita pelos seus seguidores após a sua morte, com isto "o movimento de Jesus deixa a Palestina e se espalha pelo mundo." (LIBÂNIO, 2008, p. 48). Aventamos a hipótese de que talvez pudesse ter existido um Jesuísmo baseado no Jesus palestinense sem o Cristianismo, mas o Cristianismo não existiria sem aquele. O Evangelho de João, capítulo 1:1, define este Jesus nazareno que vivia às margens da sociedade, com os párias e pecadores como o filho de Deus: "No princípio era o Verbo e o verbo estava com Deus e o Verbo era Deus."

Sobre o sucesso absoluto de YHVH, o Deus tribal cananeu, o Senhor dos Exércitos, Guerra Junqueira (1850-1923) no controvertido Prefácio à Segunda Edição de $A$ Velhice do Padre Eterno, afirma polemicamente:

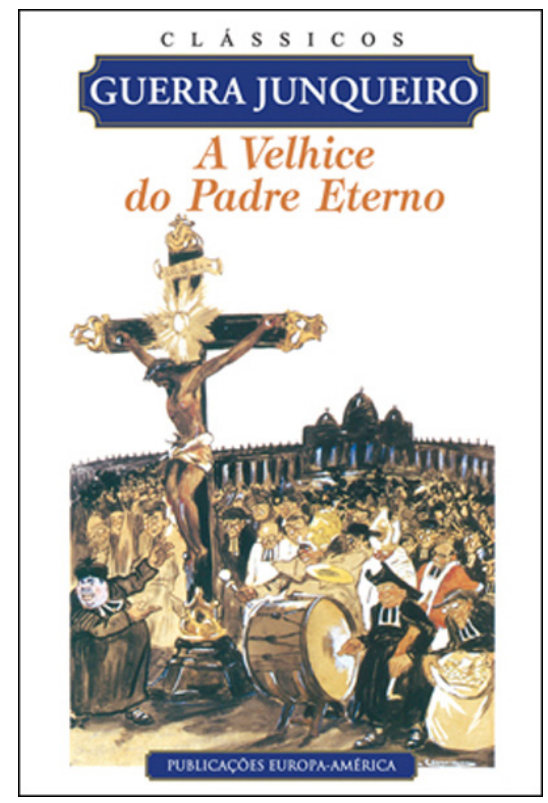

Fig. 1. A velhice do Padre Eterno I

Qual é o homem civilizado do nosso tempo que deseje ir para o Céu de Jeová, de asas brancas nas costas, desferir uma harpa ou tanger uma citara, à roda do trono do Senhor, na beatitude eterna, per omnia secula seculorum [...]. 
Do Horeb, do Gólgota e do Vaticano, trilogia espantosa, que fizeste? [...]

A acusação ai está. Agora, a defesa. Morreu o Padre Eterno? Não. Apesar de contar seis mil anos de idade e de ter já feito, à cautela, dois Testamentos, esse velho Sr. Deus dos Exércitos está ainda muito bem disposto a enterrar-nos a nós todos e aos nossos descendentes, durante esta meia dúzia de séculos mais chegados.

Tem catorze fôlegos este demónio deste Deus. Quantos colegas dele em divindade, que vieram depois, não dormem já esquecidos e extintos no grande campo-santo da mitologia, onde estão enterradas com eles no eterno silêncio as mais belas e supremas aspirações da consciência humana!

Confesso-o. Causa-me horror o Deus sanguinolento e fúnebre que separou o homem da Natureza, - que disse ao filho: Cospe em tua mãe!

No entanto, reconheço-o, de todos os Deuses existentes é Jeová quem ocupa ainda no Céu Largo das Religiões o mais belo e sumptuoso dos palácios. Brama e Buda vivem menos mal, mas no fim de contas são dois criados de servir da Rússia e da Inglaterra e portanto de Jeová, - Pai e Filho.

Quem diria que este truculento Sr. Padre Eterno, um pobre Deus semita, desprotegido e bárbaro, um Deus de $4^{\mathrm{a}}$ ou $5^{\mathrm{a}}$ classe, havia de fazer uma carreira tão longa e tão brilhante! Ele, que conhecera Júpiter TodoPoderoso, dominando o Olimpo e trovejando lá de cima: - «O universo sou eu!» - quando havia de supor que o grande Deus helénico morreria tão depressa, deixando-lhe o seu Versalhes sabrenatural, dum luxo quimérico, para ele instalar a sua corte desgrenhada e mística, de profetas selvagens e de anacoretas cavernosos, calcando uma face de luar e de olhos azuis, húmidos de esperança, fitos na última lágrima da noite - que é a primeira estrela da manhã! 
Teve sorte o velhote! Ele, que habitou lá em cima uma vetusta trapeira desconhecida e infecta, acharse de repente nas Tulherias dos Deuses, no Olimpo! Que delícia! O Criador selvagem, o Átila furibundo, castrado e piolhoso, ver-se de surpresa no luxo resplandecente da Grécia de Alexandre e da Roma dos Césares! Job em casa de Lúculo! Ezequiel à mesa de Vitélio! Ah, na primeira noite em que o Deus dos Exércitos dormiu na cama de Júpiter - Sardanápalo, ele achou naturalmente bem preferível as molezas lúbricas da Assíria e da Pérsia aos areais flamejantes do seu deserto, aos basaltos calcinados da sua recozida Palestina!

Civilizou-se. Ao deitar-se, era ainda um bárbaro; quando se levantou, era já um corrupto.

Nessa primeira noite de Olimpo, Jeová não pregou olho, decerto.

Era natural. O Deus de Jerusalém, castrado, feroz, porco, cheirando a alho, um Deus cujo reino, na geografia celeste, tinha as dimensões do principado de Mónaco, encontra-se subitamente no trono de Júpiter, César todo dominador de tudo quanto existia - porque tudo fora feito por ele! (2012, p. 1-7)

O que Guerra Junqueira revive com sua crítica ácida e panfletária, já estava presente no Herege Mor Marcião de Sínope (85-160), talvez o mais brilhante herege do cristianismo primitivo, que ao definir o seu Cânon, simplesmente não aceitava o Velho Testamento, porque considerava o YHWH muito violento e sanguinário. Para Marcião eram dois deuses completamente diferentes, não havia nenhuma evolução de um Deus guerreiro, O Senhor dos Exércitos, para um Deus Bom, encarnado na figura de Jesus, O Filho do Homem. A partir desta postura do arqui -herege Marcião a Igreja foi forçada a definir o seu cânon. É Jack Miles na Introdução do seu livro Deus, uma Biografia, quem afirma: "É estranho dizer isso, mas Deus não é nenhum santo.” (1997, p. 17). Marcião morreu como herege ao defender esta tese. Interessante constatarmos que José Saramago (1922-2010) o Nobel de Literatura de 1998, também não aceitava esta evolução. Basta lermos O Evangelho segundo Jesus Cristo (1991) e Caim (2009). Sem sombra de dúvidas, na obra inteira de 
Saramago, especificamente nestes dois romances o alvo é YHWY. Se no Evangelho segundo Jesus Cristo, mata definitivamente Deus, em Caim, o autor português crema as cinzas do Senhor das Guerras do Judaísmo.

Guerra Junqueira faz de seu livro um libelo denunciando as mazelas da Igreja Católica. É um anticlericalista ferrenho. Vale a pena observamos a ilustração acima. da capa publicada pela Edições Europa América. O Vaticano é transformado num picadeiro, quase um circo romano e Jesus aparece ali quase como uma palhaço mor observando a banda de clérigos, extasiada, passar. Observemos abaixo mais uma ilustração deste livro. A ilustração abaixo diz tudo: Cruz e Espada, juntas no domínio do mundo.

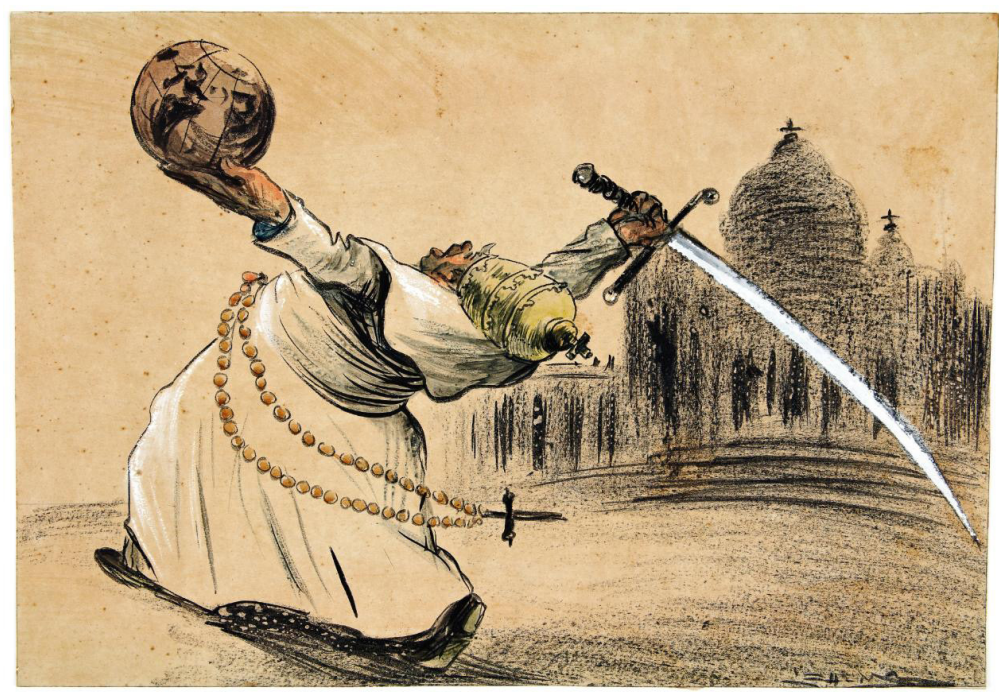

Fig. 2. A Velhice co Padre Eterno II

\section{É YHWH, quem no Monte Sinai, dá a Moisés os Dez} Mandamentos, um decálogo duro de cumprir, que apresenta mais negativas ou uma infinidade de nãos. É o próprio decálogo do não, conforme grifamos no texto abaixo: 
Os Dez Mandamentos - Êxodo 20. 1 a 17

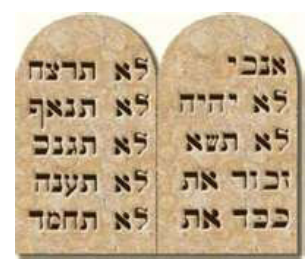

Fig. 3. Os Dez Mandamentos

1 - Então falou Deus todas estas palavras, dizendo: Eu sou o Senhor teu Deus, que te tirei da terra do Egito, da casa da servidão. Não terás outros deuses diante de mim.

2 - Não farás para ti imagem de escultura, nem alguma semelhança do que há em cima nos céus, nem em baixo na terra, nem nas águas debaixo da terra. Não te encurvarás a elas nem as servirás; porque eu, o Senhor teu Deus, sou Deus zeloso, que visito a iniqüidade dos pais nos filhos, até a terceira e quarta geração daqueles que me odeiam. E faço misericórdia a milhares dos que me amam e aos que guardam os meus mandamentos.

3 - Não tomarás o nome do Senhor teu Deus em vão; porque o Senhor não terá por inocente o que tomar o seu nome em vão.

4 - Lembra-te do dia do sábado, para o santificar. Seis dias trabalharás, e farás toda a tua obra. Mas o sétimo dia é o sábado do Senhor teu Deus; não farás nenhuma obra, nem tu, nem teu filho, nem tua filha, nem o teu servo, nem a tua serva, nem o teu animal, nem o teu estrangeiro, que está dentro das tuas portas. Porque em seis dias fez o Senhor os céus e a terra, o mar e tudo que neles há, e ao sétimo dia descansou; portanto abençoou o Senhor o dia do sábado, e o santificou.

5 - Honra a teu pai e a tua mãe, para que se prolonguem os teus dias na terra que o Senhor teu Deus te dá. 
6 - Não matarás.

7 - Não adulterarás.

8 - Não furtarás.

9 - Não dirás falso testemunho contra o teu próximo.

10 - Não cobiçarás a casa do teu próximo, não cobiçarás a mulher do teu próximo, nem o seu servo, nem a sua serva, nem o seu boi, nem o seu jumento, nem coisa alguma do teu próximo.

São exatos dez não, é própria aliança do não, das proibições. Quão dificil é para os simples mortais viverem debaixo da Lei, mas Dura lex sed lex. O Deus Guerreiro dos judeus não conhecia a letra de música de Caetano Veloso É Proibido Proibir: E eu digo não/E eu digo não ao não/ eu digo É!/ Proibido proibir!

Observemos agora As Bem-aventuranças, contidas no Sermão da Montanha, relatadas no Evangelho Segundo São Mateus 5:1-48, na Versão da Bíblia realizada por João Ferreira de Almeida:

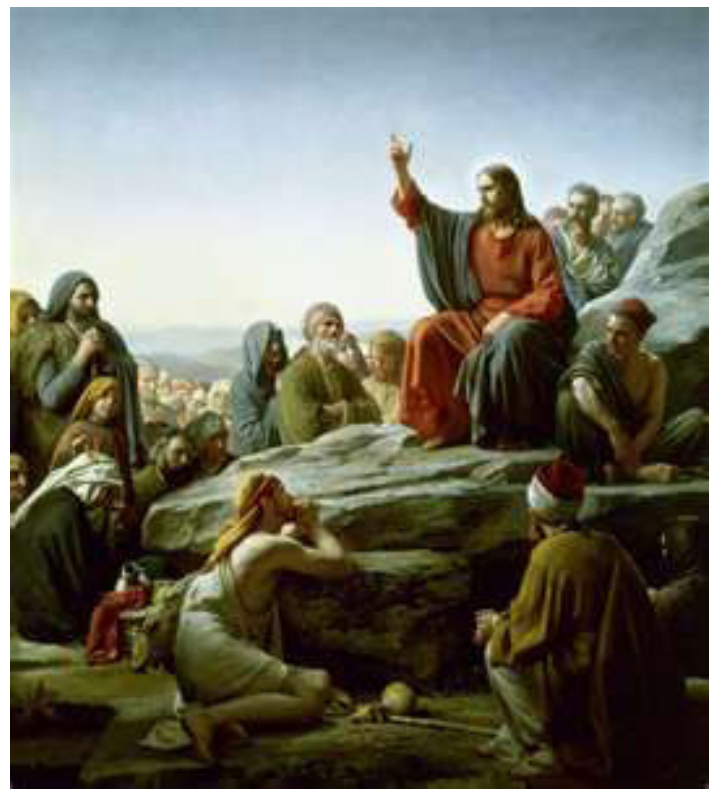

Fig. 4. Sermão da Montanha 
E Jesus, vendo a multidão, subiu a um monte, e, assentando-se, aproximaram-se dele os seus discípulos;

E, abrindo a sua boca, os ensinava, dizendo:

Bem-aventurados os pobres de espírito, porque deles é o reino dos céus;

Bem-aventurados os que choram, porque eles serão consolados;

Bem-aventurados os mansos, porque eles herdarão a terra;

Bem-aventurados os que têm fome e sede de justiça, porque eles serão fartos;

Bem-aventurados os misericordiosos, porque eles alcançarão misericórdia;

Bem-aventurados os limpos de coração, porque eles verão a Deus;

Bem-aventurados os pacificadores, porque eles serão chamados filhos de Deus;

Bem-aventurados os que sofrem perseguição por causa da justiça, porque deles é o reino dos céus;

Bem-aventurados sois vós, quando vos injuriarem e perseguirem e, mentindo, disserem todo o mal contra vós por minha causa.

Exultai e alegrai-vos, porque é grande o vosso galardão nos céus; porque assim perseguiram os profetas que foram antes de vós.

Vós sois o sal da terra; e se o sal for insípido, com que se há de salgar? Para nada mais presta senão para se lançar fora, e ser pisado pelos homens.

Vós sois a luz do mundo; não se pode esconder uma cidade edificada sobre um monte;

Nem se acende a candeia e se coloca debaixo do alqueire, mas no velador, e dá luz a todos que estão na casa. 
Assim resplandeça a vossa luz diante dos homens, para que vejam as vossas boas obras e glorifiquem a vosso Pai, que está nos céus.

Não cuideis que vim destruir a lei ou os profetas: não vim ab-rogar, mas cumprir.

\section{Porque em verdade vos digo que, até que o céu e a terra passem, nem um jota ou um til se omitirá da lei, sem que tudo seja cumprido.}

Qualquer, pois, que violar um destes mandamentos, por menor que seja, e assim ensinar aos homens, será chamado o menor no reino dos céus; aquele, porém, que os cumprir e ensinar será chamado grande no reino dos céus.

Porque vos digo que, se a vossa justiça não exceder a dos escribas e fariseus, de modo nenhum entrareis no reino dos céus.

Ouvistes que foi dito aos antigos: Não matarás; mas qualquer que matar será réu de juízo.

Eu, porém, vos digo que qualquer que, sem motivo, se encolerizar contra seu irmão, será réu de juízo; e qualquer que disser a seu irmão: Raca, será réu do sinédrio; e qualquer que lhe disser: Louco, será réu do fogo do inferno.

Portanto, se trouxeres a tua oferta ao altar, e aí te lembrares de que teu irmão tem alguma coisa contra ti,

Deixa ali diante do altar a tua oferta, e vai reconciliar-te primeiro com teu irmão e, depois, vem e apresenta a tua oferta.

Concilia-te depressa com o teu adversário, enquanto estás no caminho com ele, para que não aconteça que o adversário te entregue ao juiz, e o juiz te entregue ao oficial, e te encerrem na prisão.

Em verdade te digo que de maneira nenhuma sairás dali enquanto não pagares o último ceitil.

Ouvistes que foi dito aos antigos: Não cometerás adultério. 
$\mathrm{Eu}$, porém, vos digo, que qualquer que atentar numa mulher para a cobiçar, já em seu coração cometeu adultério com ela.

Portanto, se o teu olho direito te escandalizar, arranca-o e atira-o para longe de ti; pois te é melhor que se perca um dos teus membros do que seja todo o teu corpo lançado no inferno.

$\mathrm{E}$, se a tua mão direita te escandalizar, corta-a e atira-a para longe de ti, porque te é melhor que um dos teus membros se perca do que seja todo o teu corpo lançado no inferno.

Também foi dito: Qualquer que deixar sua mulher, dê-lhe carta de desquite.

Eu, porém, vos digo que qualquer que repudiar sua mulher, a não ser por causa de prostituição, faz que ela cometa adultério, e qualquer que casar com a repudiada comete adultério.

Outrossim, ouvistes que foi dito aos antigos: Não perjurarás, mas cumprirás os teus juramentos ao Senhor.

Eu, porém, vos digo que de maneira nenhuma jureis; nem pelo céu, porque é o trono de Deus;

Nem pela terra, porque é o escabelo de seus pés; nem por Jerusalém, porque é a cidade do grande Rei;

Nem jurarás pela tua cabeça, porque não podes tornar um cabelo branco ou preto.

Seja, porém, o vosso falar: Sim, sim; Não, não; porque o que passa disto é de procedência maligna.

Ouvistes que foi dito: Olho por olho, e dente por dente.

Eu, porém, vos digo que não resistais ao mal; mas, se qualquer te bater na face direita, oferece-lhe também a outra;

E, ao que quiser pleitear contigo, e tirar-te a túnica, larga-lhe também a capa; 
E, se qualquer te obrigar a caminhar uma milha, vai com ele duas.

Dá a quem te pedir, e não te desvies daquele que quiser que the emprestes.

Ouvistes que foi dito: Amarás o teu próximo, e odiarás o teu inimigo.

Eu, porém, vos digo: Amai a vossos inimigos, bendizei os que vos maldizem, fazei bem aos que vos odeiam, e orai pelos que vos maltratam e vos perseguem; para que sejais filhos do vosso Pai que está nos céus;

Porque faz que o seu sol se levante sobre maus e bons, e a chuva desça sobre justos e injustos.

Pois, se amardes os que vos amam, que galardão tereis? Não fazem os publicanos também o mesmo?

E, se saudardes unicamente os vossos irmãos, que fazeis de mais? Não fazem os publicanos também assim?

Sede vós pois perfeitos, como é perfeito o vosso Pai que está nos céus." (Versão eletrônica, negritos nossos)

Citamos uma parte a mais do Sermão da Montanha dada a sua rara beleza! Não queremos passar nenhum sermão aqui, mas este texto é mais do necessário neste mundo doente, hospedado numa UTI, de tanta frieza, maldade, ostentação, falta de amor, em que muitos se curvam para o solo, só vêm a si e seu umbigo, não veem o próximo, em que muitos já morreram, apenas não foram avisados disto. Voltando ao texto e nos desculpando o sermão em cima do sermão, centremos nossa análise no núcleo do Sermão da Montanha - As Bem- Aventuranças. Não existe não. Ao decálogo do não do Sinai, opõem-se o decálogo do Bem, da felicidade. Na Bíblia de Jerusalém o adjetivo Bem-Aventurados da versão Almeida é substituído pelo adjetivo felizes: 
Felizes os pobres no espírito, porque deles é o Reino dos Céus.

Felizes os mansos, porque herdarão a terra.

Felizes os aflitos, porque serão consolados.

Felizes os que têm fome e sede de justiça, porque serão saciados.

Felizes os que são misericordiosos, porque alcançarão misericórdia.

Felizes os puros no coração, porque verão a Deus.

Felizes os que promovem a paz, porque serão chamados filhos de Deus.

Felizes os que são perseguidos por causa da justiça, porque deles é o Reino do céu.

Felizes sois, quando vos injuriarem e vos perseguirem, e, mentindo, disserem todo o mal contra vós, por causa de mim.

Alegrai-vos e regozijai-vos, porque será grande a vossa recompensa nos céus. para vocês a recompensa no céus. Pois foi assim que perseguiram os profetas que vieram antes de vós." (2011, Mt $5: 3-12)$

Embora, Jesus afirme que nem um jota ou um til passará da lei, os seus conselhos são radicalmente mais leves que dura Lei de YHWH. O Sermão da Montanha tem uma suavidade, humanidade e positivismo que o Decálogo do Sinai em absoluto não tinha.

Talvez seja esta suavidade, este tom de conselho e autoajuda, foi que fez e faz com que o Sermão da Montanha seja muito mais parodiado na Literatura do que os Dez Mandamentos. Não é fácil brincar com YHWH! Georges Minois em História do Riso e do Escárnio afirma “... o riso não é natural no cristianismo, religião séria por excelência. [...] Do que poderia rir um Ser todo poderoso, perfeito, que se basta a si mesmo, sabe tudo, vê tudo e pode tudo?” (2003, p. 111). Genialmente Minois nos faz acreditar em sua tese, até a metade do livro, quando debocha do leitor e diz: há muito riso na Bíblia e próprio YHWH ri de seus inimigos. Mas o que nos interessa foi que esta imagem de um cristianismo sério foi que pesou no ocidente: basta observamos que a imagem que ficou como ícone 
maior deste movimento que mudou radicalmente a face do ocidente foi o Cristo assustadoramente sofredor na Cruz e não sua imagem tranquila e poderosa, ressurreto vencendo a morte. O Filme A Paixão de Cristo (2004) de Mel Gibson é uma elegia ao sofrimento e ao sangue, parece um filme de terror. Escorre sangue da tela e a ressurreição ocupa menos de 2 segundo no final. $O$ filme foi um estrondoso sucesso, cristãos de todas as denominações assistiam o filme em suas próprias igrejas e choravam, choravam, quase lágrimas de sangue.

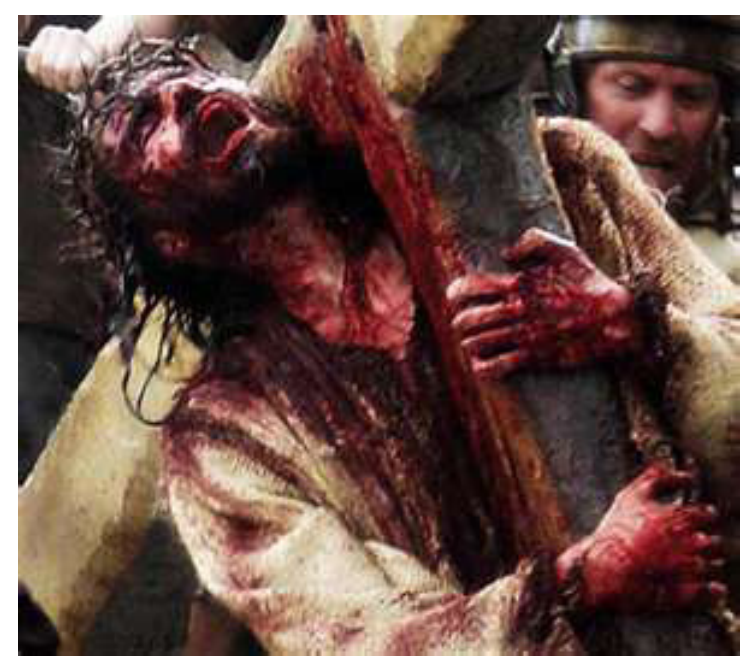

Fig. 5. A Paixão de Cristo (שי לש וויספה), Mel Gibson (2004)

Há necessidade de se ter coragem para brincar com o Senhor dos Exércitos, o Eu sou o que Sou do Judaísmo. Lembramos aqui a magnífica paródia dos Simpsons aos Dez Mandamentos, na segunda temporada apresentada em 1991, no episódio intitulado Homer contra Lisa e o 8. Mandamento, parodiando o filme Os Dez Mandamentos (1956), de Cecil B Demille.

Analisemos a seguir a divertida paródia Ao Sermão da Montanha, de Machado de Assis (1839-1908), publicado na Gazeta de Notícias em 1892. 


\section{O Sermão do Diabo}

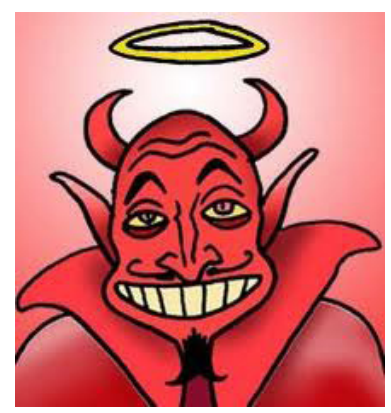

Fig. 6. O Diabo

Nem sempre respondo por papéis velhos: mas aqui está um que parece autêntico; e, se o não é, vale pelo texto, que é substancial. É um pedaço do evangelho do Diabo, justamente um sermão da montanha, à maneira de São Mateus. Não se apavorem as almas católicas. Já Santo Agostinho dizia que "a igreja do Diabo imita a igreja de Deus". Daí a semelhança entre os dois evangelhos. Lá vai o do Diabo:

"E vendo o Diabo a grande multidão de povo, subiu a um monte, por nome Corcovado, e, depois de se ter sentado, vieram a ele os seus discípulos.

E ele, abrindo a boca, ensinou dizendo as palavras seguintes.

Bem-aventurados aqueles que embaçam, porque eles não serão embaçados.

Bem-aventurados os afoitos, porque eles possuirão a terra.

Bem-aventurados os limpos das algibeiras, porque eles andarão mais leves.

Bem-aventurados os que nascem finos, porque eles morrerão grossos.

Bem-aventurados sois, quando vos injuriarem e disserem todo o mal, por meu respeito. 
Folgai e exultai, porque o vosso galardão é copioso na terra.

Vós sois o sal do money market. E se o sal perder a força, com que outra coisa se há de salgar?

Vós sois a luz do mundo. Não se põe uma vela acesa debaixo de um chapéu, pois assim se perdem o chapéu e a vela.

Não julgueis que vim destruir as obras imperfeitas, mas refazer as desfeitas.

Não acrediteis em sociedades arrebentadas. Em verdade vos digo que todas se consertam, e se não for com remendo da mesma cor, será com remendo de outra cor.

Ouvistes que foi dito aos homens: Amai-vos uns aos outros. Pois eu digo-vos: Comei-vos uns aos outros; melhor é comer que ser comido; o lombo alheio é muito mais nutritivo que o próprio.

Também foi dito aos homens: Não matareis a vosso irmão, nem a vosso inimigo, para que não sejais castigados. Eu digo-vos que não é preciso matar a vosso irmão para ganhardes o reino da terra; basta arrancar-lhe a última camisa.

Assim, se estiveres fazendo as tuas contas, e te lembrar que teu irmão anda meio desconfiado de ti, interrompe as contas, sai de casa, vai ao encontro de teu irmão na rua, restitui-lhe a confiança, e tira-lhe o que ele ainda levar consigo.

Igualmente ouvistes que foi dito aos homens: Não jurareis falso, mas cumpri ao Senhor os teus juramentos.

Eu, porém, vos digo que não jureis nunca a verdade, porque a verdade nua e crua, além de indecente, é dura de roer; mas jurai sempre e a propósito de tudo, porque os homens foram feitos para crer antes nos que juram falso, do que nos que não juram nada. Se disseres que o sol acabou, todos acenderão velas. 
Não façais as vossas obras diante de pessoas que possam ir contá-lo à polícia.

Quando, pois, quiserdes tapar um buraco, entendei-vos com algum sujeito hábil, que faça treze de cinco e cinco.

Não queirais guardar para vós tesouros na terra, onde a ferrugem e a traça os consomem, e donde os ladrões os tiram e levam.

Mas remetei os vossos tesouros para algum banco de Londres, onde a ferrugem, nem a traça os consomem, nem os ladrões os roubam, e onde ireis vê-los no dia do juízo.

Não vos fieis uns nos outros. Em verdade vos digo, que cada um de vós é capaz de comer o seu vizinho, e boa cara não quer dizer bom negócio.

Vendei gato por lebre, e concessões ordinárias por excelentes, a fim de que a terra se não despovoe das lebres, nem as más concessões pereçam nas vossas mãos.

Não queirais julgar para que não sejais julgados; não examineis os papéis do próximo para que ele não examine os vossos, e não resulte irem os dous para a cadeia, quando é melhor não ir nenhum.

Não tenhais medo às assembléias de acionistas, e afagai-as de preferência às simples comissões, porque as comissões amam a vangloria e as assembléias as boas palavras.

As porcentagens são as primeiras flores do capital; cortai-as logo, para que as outras flores brotem mais viçosas e lindas.

Não deis conta das contas passadas, porque passadas são as contas contadas, e perpétuas as contas que se não contam.

Deixai falar os acionistas prognósticos; uma vez aliviados, assinam de boa vontade. 
Podeis excepcionalmente amar a um homem que vos arranjou um bom negócio; mas não até o ponto de o não deixar com as cartas na mão, se jogardes juntos.

Todo aquele que ouve estas minhas palavras, e as observa, será comparado ao homem sábio, que edificou sobre a rocha e resistiu aos ventos; ao contrário do homem sem consideração, que edificou sobre a areia, e fica a ver navios..."

Aqui acaba o manuscrito que me foi trazido pelo próprio Diabo, ou alguém por ele; mas eu creio que era o próprio. Alto, magro, barbícula ao queixo, ar de Mefistófeles. Fiz-lhe uma cruz com os dedos e, ele sumiu-se. Apesar de tudo, não respondo pelo papel, nem pelas doutrinas, nem pelos erros de cópia. (versão on-line, 2012)

Machado de Assis, em seu texto diabólico, parodia São Mateus e humoristicamente faz o seu Sermão do Diabo. E onde mais o Diabo poderia realizar seu Sermão profano senão no Brasil, senão no Corcovado, senão no Rio de Janeiro, terra das mulatas e do carnaval! Se Deus é brasileiro, o Diabo também o é. Em seu livro O Diabo nos porões da caravela, a crítica Iza Gomes Chain realiza um estudo sobre a influência das crenças do povo português no Brasil recém-descoberto, principalmente no que diz respeito às figuras centrais do cristianismo. Lendo seu livro e suas pertinentes observações, podemos dizer que o brasileiro, ao assimilar o arcabouço mental português, misturado com as crenças africanas e indígenas, desteologizou o Diabo. O Diabo não mete medo em ninguém passa a ser quase um membro da família brasileira, traquino e astuto, basta ver as seguintes imprecações comuns em todo o Brasil: Oh! diacho, menino encapetado, endiabrado, o diabo que te carregue, sai deste corpo que não te pertence, etc. Machado poderia ter incluído, ou melhor, repetido no seu Sermão do Diabo, uma fala genial presente no conto A Igreja do Diabo, publicado em 1884. O Diabo, cansado de viver na periferia do Cristianismo, e viver somente das sobras de Deus e do Céu, resolve fundar sua própria Igreja. Uma de suas principais regras e máximas é: "Leve a breca o próximo! Não há próximo! A única hipótese 
em que ele permitia amar ao próximo era quando se tratasse de amar as damas alheias, porque essa espécie de amor tinha a particularidade de não ser outra coisa mais do que o amor do indivíduo a si mesmo." (versão on-line 2012, negrito nosso)

Já o escritor argentino Jorge Luis Borges (1899-1986), um dos maiores representantes da literatura latino americana, tinha como um de suas temáticas preferidas o diálogo intertextual com a Bíblia, com o Judaísmo e o Cristianismo. Este aspecto já foi devidamente explorado em livros e centenas de artigos. Contemplemos esta sutileza de obra de arte parodística de Borges intitulada Fragmentos de um Evangelio Apócrifo, extraído do livro Elogio da Sombra, publicado em 1969. Com toda tradução é uma última análise uma traição, citamos no original.

\section{Fragmentos de um Evangelio apócrifo}

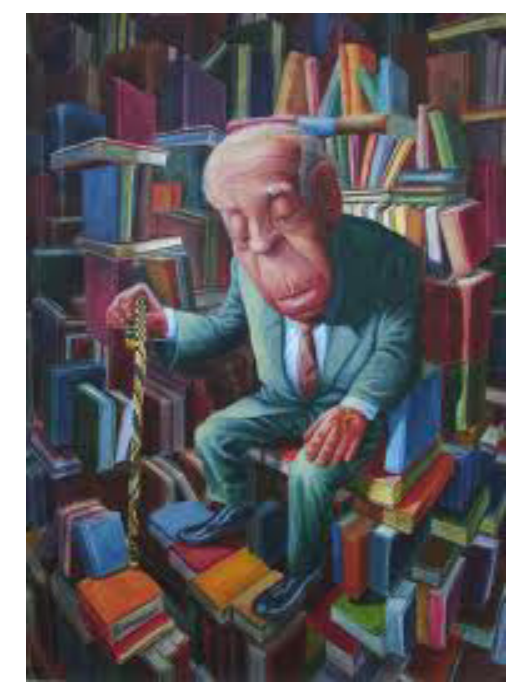

Fig. 7. Jorge Luiz Borges e sua biblioteca

Desdichado el pobre en espíritu, porque bajo la tierra será lo que ahora es en la tierra.

Desdichado el que llora, porque ya tiene el hábito miserable del llanto.

Dichosos los que saben que el sufrimiento no es una corona de gloria.

No basta ser el último para ser alguna vez el primero. 
Feliz el que no insiste en tener razón, porque nadie la tiene o todos la tienen.

Feliz el que perdona a los otros y el que se perdona a sí mismo.

Bienaventurados los mansos, porque no condescienden a la discordia.

Bienaventurados los que no tienen hambre de justicia, porque saben que nuestra suerte, adversa o piadosa, es obra del azar, que es inescrutable.

Bienaventurados los misericordiosos, porque su dicha está en el ejercicio de la misericordia y no en la esperanza de un premio.

Bienaventurados los de limpio corazón, porque ven a Dios.

Bienaventurados los que padecen persecución por causa de la justicia, porque les importa más la justicia que su destino humano.

Nadie es la sal de la tierra, nadie, en algún momento de su vida, no lo es.

Que la luz de una lámpara se encienda, aunque ningún hombre la vea. Dios la verá.

No hay mandamiento que no pueda ser infringido, y también los que digo y los que los profetas dijeron. El que matare por la causa de la justicia, o por la causa que él cree justa, no tiene culpa.

Los actos de los hombres no merecen ni el fuego ni los cielos.

No odies a tu enemigo, porque si lo haces, eres de algún modo su esclavo. Tu odio nunca será mejor que tu paz.

Si te ofendiere tu mano derecha, perdónala; eres tu cuerpo y eres tu alma y es arduo, o imposible, fijar la frontera que los divide...

No exageres el culto de la verdad; no hay hombre que al cabo de un día, no haya mentido con razón muchas veces.

No jures, porque todo juramento es un énfasis. 
Resiste al mal, pero sin asombro y sin ira. A quien te hiriere en la mejilla derecha, puedes volverle la otra, siempre que no te mueva el temor.

Yo no hablo de venganza ni de perdones; el olvido es la única venganza y el único perdón. Hacer el bien a tu enemigo puede ser obra de justicia y no es arduo; amarlo, tarea de ángeles y no de hombres.

Hacer el bien a tu enemigo es el mejor modo de complacer tu vanidad.

No acumules oro en la tierra, porque el oro es padre del ocio, y éste, de la tristeza y el tedio.

Piensa que los otros son justos y lo serán, y si no es así, no es tuyo el error.

Dios es más generoso que los hombres y los medirá con otra medida.

Da lo santo a los perros, echa tus perlas a los puercos; lo que importa es dar.

Busca por el agrado de buscar, no por el de encontrar...

La puerta es la que elige, no el hombre.

No juzgues al árbol por sus frutos ni al hombre por sus obras; pueden ser peores o mejores.

Nada se edifica sobre la piedra, todo sobre la arena, pero nuestro deber es edificar como si fuera piedra la arena...

Feliz el pobre sin amargura o el rico sin soberbia.

Felices los valientes, los que aceptan con ánimo parejo la derrota o las palmas.

Felices los que guardan en la memoria palabras de Virgilio o de Cristo, porque éstas darán a luz a sus días.

Felices los amados y los amantes y los que pueden prescindir del amor.

Felices los felices. (versão on-line, 2012, negritos nossos) 
Borges suaviza ainda mais o já suave Sermão da Montanha. Eis aqui a riqueza da Bíblia que funciona como um arca que sempre pode ser saqueada por todos os escritores de todos os tempos. Não há temas novos, mas o gênio sabe saquear o que veio antes dele e deixar a sua assinatura. Se Jesus revoluciona o judaísmo com seu Sermão da Montanha, suas bem-aventuranças, Borges a partir do texto de Jesus, efetiva suas Bemaventuranças Apócrifas. Mas aqui Apócrifo é usado no sentido primeiro do grego $\alpha \pi$ óкрvфо ; do latim apócryphus, vertido para português no sentido de oculto, não de falso, como vulgarmente o termo passou a designar. Borges humaniza mais ainda o Sermão da Montanha, que na sua versão poderia ser denominada de Sermão do Humano, porque compreende que certas coisas só são possíveis a anjos, não a humanos. Ao não mentirás cristão, Borges diz que não há um homem que ao cabo de um dia não tenha proferido uma mentira sequer. Jesus relê o Velho Testamento: "Ouvistes que foi dito: Amarás o teu próximo, e odiarás o teu inimigo. Eu, porém, vos digo: Amai a vossos inimigos, bendizei os que vos maldizem, fazei bem aos que vos odeiam, e orai pelos que vos maltratam..." (Mateus 5: 20). Mas Borges relê Jesus ampliando mais ainda a sua condescendência com os humanos: "Hacer el bien a tu enemigo puede ser obra de justicia y no es arduo; amarlo, tarea de ángeles y no de hombres." Jesus, filho de Deus e de uma humana, portanto, Deus e Homem, nos aconselha amar os nossos inimigos. Já Borges sendo só humano nos desculpa e afirma que amar os inimigos é obra de anjos e nós não somos anjos, somos apenas e miseravelmente homens. É muito para nós!

Seu Sermão do Humano é generoso demais. Enquanto o Evangelista Mateus afirma em seu livro capítulo 7:6 - "Não deis aos cães as coisas santas, nem deis aos porcos as vossas pérolas, não aconteça que as pisem com os pés e, voltando-se, vos despedacem.”, Borges caminha a segunda milha: "Da lo santo a los perros, echa tus perlas a los puercos; lo que importa es dar." O pregador argentino termina sua predica com um benção: Felices los felices.

A paródia evangélica encontra sua radicalidade naquilo que denominamos de Mal-Aventuranças, presentes na denominada Bíblia Satânica (The Satanic Bible), um livro escrito pelo autodenominado satanista Anton Szandor LaVey em 1969. La Vey nasceu em Chicago em 1930 e morreu em São Francisco em 1997, tendo fundado a chamada Igreja de Satã (Church of Satan) em Abril de 1966. Sua igreja é anticristã, combate a 
repressão sexual e o sentimento de culpa. Esta Bíblia Satânica contêm uma coleção de ensaios, observações e rituais mágicos que formam o núcleo temático do que ficou conhecido como Satanismo de LaVey, que prioriza Satanás como a força motriz que move a natureza e todos os mundos. Para os satanista de LaVey, o termo é usado no sentido de adversário, e não como o demônio do monoté́smo cristão. Citemos as Mal- Aventuranças da Bíblia Satânica de LaVey:

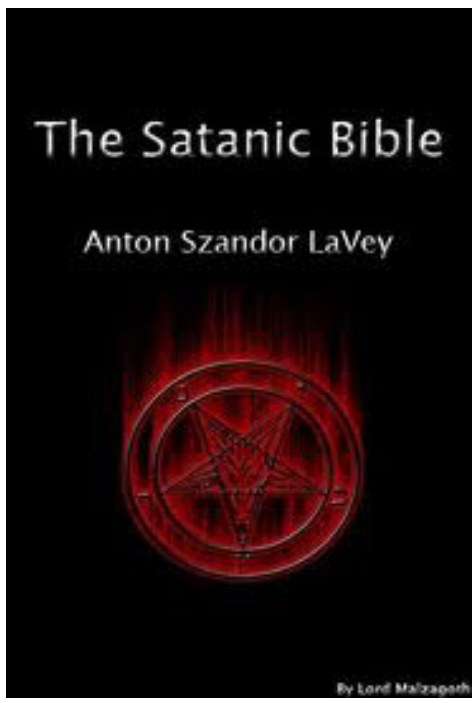

Fig. 8. The Satanic Bible

Abençoados são os fortes, pois eles possuirão a terra - Amaldiçoados são os fracos, pois eles herdarão o jugo!

Abençoados são os poderosos, pois eles serão reverenciados no meio dos homens - Amaldiçoados são os débeis, pois eles serão destruídos!

Abençoados são os corajosos, pois eles serão os mestres do mundo - Amaldiçoados são os submissos na honradez, pois eles serão pisados sobre a representação de Satã!

Abençoados são os vitoriosos, pois a vitória é a base do direito - Amaldiçoados são os conquistados, pois eles serão vassalos para sempre! 
Abençoados são os que usam mão de ferro, pois os ineptos desaparecerão antes deles - Amaldiçoados são os pobres de espírito, pois eles serão cuspidos!

Abençoados são os autodesafiadores, pois seus dias serão longos na terra - Amaldiçoados são os buscam uma vida rica antes do túmulo, pois eles perecerão no meio da abundância!

Abençoados são os destruidores da falsa esperança, pois eles são os verdadeiros Messias - Amaldiçoados são os adoradores de Deus, pois eles serão divididos pelo carneiro!

Abençoados são os valentes, pois eles obterão grande tesouro - Amaldiçoados são os crentes no bem e no mal, pois eles serão aterrorizados pelas sombras!

Abençoados são aqueles que pensam no que é melhor para si, pois suas mentes nunca serão aterrorizadas - Amaldiçoados são as "ovelhas de Deus", pois eles serão sangrados mais claro que a neve!

Abençoado é o homem que tem poucos inimigos, pois eles farão dele um herói - Amaldiçoados é o que faz o bem aos outros que o escarnecem em retorno, pois ele será desprezado!

Abençoados são os de mente poderosa, pois eles serão cavalgarão o furacão - amaldiçoados são aqueles que ensinam mentiras por verdades e verdades por mentiras, pois eles são uma abominação!

Muito amaldiçoados são os fracos cuja insegurança os tornam vis, pois eles servirão e sofrerão!

O anjo do autoilusão está acampado nas almas do honrado - A chama eterna do poder preenche de alegria interior a carne do Satanista!

Aqui não há bem-aventuranças, só maldições em forma de imprecações. Poderíamos também denominar seu Sermão de Os Bem-amaldiçoados de Satã. LaVey insulta e debocha dos cristãos e suas bem-aventuranças. O pior é contatar que talvez ele tenha razão, os fortes vencem, os fracos 
sofrem, parece que a Bíblia do chamado Príncipe das Trevas, do Papa Negro teve todas as suas profecias cumpridas! O mandamento maior do Papa Negro e da Bíblia Satânica é Morte ao fraco, saúde ao forte. Ou como diria o filósofo Quincas Borca, criação de Machado de Assis: ao vencedor as batatas...

A criatividade infinita dos textos quase anônimos que pululam na Internet é algo espantoso. Ninguém sabe de onde veio, quem começou, quem incrementou, quem acrescentou, quem corrigiu, quem editou, quem terminou, quem pôs na rede, quem divulgou. Assim surgem na internet textos quase que coletivos, sem autoria que ganham vida e acréscimo a cada vez que são consultados e lidos. O texto não é de ninguém e é de todos. É o que eu chamo de deuteronomista cibernético. Geralmente estes textos têm uma motivação para cair na rede: uma data ou acontecimento especial. Esta paródia do Sermão da Montanha apareceu no ano retrasado, por ocasião do dia do Professor. Certamente alguém, ou vários satiristas anônimos quiseram homenagear seus sofridos e injustiçados mestres. Denominei esta versão de O Sermão da Montanha na versão ao Mestre com Carinho em homenagem ao belo filme da década de sessenta intitulado Ao Mestre com carinho, com a brilhante interpretação do ator Sidney Poitier.

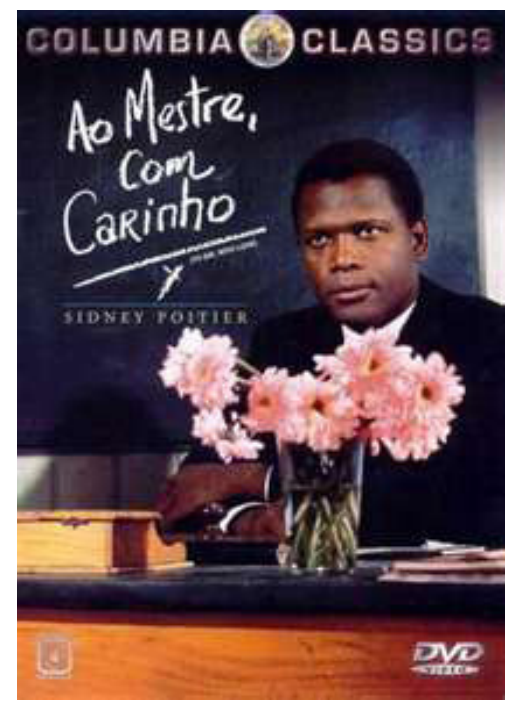

Fig. 9. Ao Mestre com carinho 
Naquele tempo, Jesus subiu a um monte seguido pela multidão e, sentado sobre uma grande pedra, deixou que os seus discípulos e seguidores se aproximassem.

Ele os preparava para serem os educadores capazes de transmitir a lição da Boa Nova a todos os homens.

Tomando a palavra, disse-lhes:

- Em verdade, em verdade vos digo:

- Felizes os pobres de espírito, porque deles é o reino dos céus.

- Felizes os que têm fome e sede de justiça, porque serão saciados.

- Felizes os misericordiosos, porque eles...?

Pedro o interrompeu:

- Mestre, vamos ter que saber isso de cor?

André perguntou:

- É pra copiar?

Filipe lamentou-se:

- Esqueci meu papiro!

Bartolomeu quis saber:

- Vai cair na prova?

João levantou a mão:

- Posso ir ao banheiro?

Judas Iscariotes resmungou:

- O que é que a gente vai ganhar com isso?

Judas Tadeu defendeu-se:

- Foi o outro Judas que perguntou!

Tomé questionou:

- Tem uma fórmula pra provar que isso tá certo?

Tiago Maior indagou:

- Vai valer nota? 
Tiago Menor reclamou:

- Não ouvi nada, com esse grandão na minha frente. Simão Zelote gritou, nervoso:

- Mas porque é que não dá logo a resposta e pronto!?

Mateus queixou-se:

- Eu não entendi nada, ninguém entendeu nada!

Um dos fariseus, que nunca tinha estado diante de uma multidão nem ensinado nada a ninguém, tomou a palavra e dirigiu-se a Jesus, dizendo:

- Isso que o senhor está fazendo é uma aula?

- Onde está o seu plano de curso e a avaliação diagnóstica?

- Quais são os objetivos gerais e específicos?

- Quais são as suas estratégias para recuperação dos conhecimentos prévios?

Caifás emendou:

- Fez uma programação que inclua os temas transversais e atividades integradoras com outras disciplinas?

- E os espaços para incluir os parâmetros curriculares gerais?

- Elaborou os conteúdos conceituais, processuais e atitudinais?

Pilatos, sentado lá no fundão, disse a Jesus:

- Quero ver as avaliações da primeira, segunda e terceira etapas e reservo-me o direito de, ao final, aumentar as notas dos seus discípulos para que se cumpram as promessas do Imperador de um ensino de qualidade.

- Nem pensar em números e estatísticas que coloquem em dúvida a eficácia do nosso projeto.

- E vê lá se não vai reprovar alguém!

E, foi nesse momento que Jesus disse: "Senhor, por que me abandonastes..." 
Ou seja, se Jesus fosse professor, coitado dele, seu ministério teria acabado nas primeiras palavras do seu magistério!

Há um livro de ficção que aborda a questão da intertextualidade de forma criativa. Trata-se do livro do escritor anglo-indiano Salman Rushdie, escrito justamente quando ele fugia do fundamentalismo islâmico do Irã que decretou contra ele uma sentença de morte (fatwa) em 1989, logo após ter escrito seu polêmico livro Versos Satânicos. O livro infantojuvenil, impressionante conto de fadas moderno, intitula-se Haroun e o Mar de Histórias, publicado em 1990. O menino Haroun era filho de um contador de estórias - Rashid. Seu pai, após ser traído por sua mãe, que havia fugido com o vizinho, perdeu a capacidade de narrar estórias. Ele ganhava a vida contando estórias. Rashid recebia, pela torneira da casa, a água das histórias, que vinha de uma segunda lua da terra que nunca fora rastreada: Kahani. Rashid perdeu a alegria de viver, cancelou o fornecimento da água das histórias. Seu filho Haroun, com a ajuda de um gênio chamado Iff, viajou até essa lua para tentar reverter o cancelamento da água das histórias. Não vamos contar toda a estória, mas o que nos interessa é a parte em que Haroun chega a lua Kahani e encontra o magnífico Mar de Fios de Histórias:

Olhou para a água e reparou que ela era feita de milhares e milhares de correntes diferentes, cada uma de uma cor diferente, que se entrelaçavam como uma tapeçaria líquida, de uma complexidade de tirar o fôlego; e Iff explicou que aqueles eram os Fios de Histórias, e que cada fio colorido representava e continha uma única narrativa. Em diferentes áreas do oceano, havia diferentes tipos de histórias, e como todas as histórias que já foram contadas e muitas das que ainda estavam sendo inventadas podiam se encontrar ali, o Mar de Fios de Histórias era, na verdade, a maior biblioteca do universo. E como as histórias ficavam guardadas ali em forma fluída, elas conservavam a capacidade de mudar, de se transformar em novas versões de si mesmas, de se unir a outras histórias, de modo que, ao contrário de uma biblioteca de livros, o Mar de Fios de Histórias era muito mais que 
um simples depósito de narrativas. Não era um lugar morto, mas cheio de vida" (RUSHDIE, 2008, s/p negrito nosso).

A pesquisadora da UFSC, Gilka Giradello, analisando o livro de Salman Rushie, afirma que:

\section{O Mar de Fios de Histórias é aí uma metáfora} para a textura narrativa da cultura. Quanto mais intrincada, colorida e diversa essa textura, mais vivo estará o mar (...). A arte narrativa aparece aí como um mecanismo inerente ao tecido da cultura.

Como há milhares de peixes, mil bocas no mar, fica claro que a tarefa recriadora pertence ao conjunto da viva tapeçaria líquida da cultura.

Há milhares de fios de histórias, há milhares de peixes no mar: a vitalidade da cultura aparece nessa imagem de Salman Rushdie como inseparavelmente ligada à biodiversidade do mar de histórias. O mar de histórias é uma imagem poética muito forte, presente há séculos na imaginação da humanidade. Essa imagem dá conta de um certo caráter "líquido" das histórias — fluido, mutável — que volta e meia é percebido pelas pessoas que pensam sobre narrativa. (2010, p. 3, negrito nosso)

E nossos escritores aqui citados: Machado de Assis, Jorge Luiz Borges, LaVey, e os anônimos da Internet fazem o papel de Peixe mil bocas, mergulham na tapeçaria líquida do grande mar de História que é a Bíblia, trituram o antigo e apresentam com uma maravilhosa roupagem, assinam as suas bem ou aventuranças, demonstrando que não há nada de novo debaixo da terra, mas que suas obras são reescrituras de obras do passado, com a assinatura do gênio. Ou como dizia Paulo Leminski em Ensaios Crípticos: "A literatura é telepatia com todo o passado, as obras são variantes de todas as obras anteriores. Não é o indivíduo que faz literatura, é a humanidade" (1986, s/p, negrito nosso.) Para Leminski, a intertextualidade é condição primordial da criação literária.

Bem-aventurados sois vós leitor que tivestes a oportunidade de conhecer todas estas paródias das Bem-Aventuranças! 


\section{Bibliografia}

ASSIS, MACHADO. A Igreja do Diabo. Disponível em: < http://www. dominiopublico.gov.br/pesquisa/DetalheObraForm.do?select_action $=\& c 0$ obra $=1903>$. Acesso em: 30 maio 2012.

O Sermão do Diabo. Disponível em: < http://pt.wikisource.org/ wiki/O_Serm\%C3\%A3o_do_Diabo>. Acesso em: 30 maio 2012.

BÍBLIA de Jerusalém. Ed. rev. e ampl. 7. reimpressão. São Paulo: Paulus, 2011.

BÍBLIA Sagrada. Trad. João F. de Almeida. Versão atualizada. Disponível em: $<$ http://www.luteranos.com.br/biblia/portugues/portugues.html>. Acesso em 4 jun. 2012.

BLOOM, Harold. A angústia da influência: uma teoria da poesia. 2. ed. Trad. Marcos Santarrita. Rio de Janeiro: Imago, 2002.

BORGES, Jorge Luis. Elogio da Sombra. In. Obras Completas. Vol. II 1952-1972. 2. reimpressão. São Paulo: Globo, 2000. Disponível em: <http:// pt.scribd.com/doc/27751535/BOR GES-Jorge-Luis-Elogia-Da-Sombra>. Acesso em: 30 maio 2012.

CHAIN, Iza Gomes da Cunha._O Diabo nos Porões das Caravelas. Juiz de Fora: EUFJF, 2003.

FINKELSTEIN, Israel; SILBERMAN, Neil Asher. A Bíblia não tinha razão. Trad. Tuca Magalhães. São Paulo: Giafa, 2003.

GIRARDELLO, Gilka. A Imaginação Infantil e as Histórias da TV. Ateliê da Aurora/NICA, artigos, 2010, p. 1-7. Disponível em: <http://www. nica.ufsc.br/wp-content/uploads/2010/01/A-imaginacao-da-infantil-eas-historias-da-tv.pdf $>$. Acesso em: 22 set. jun. 2010.

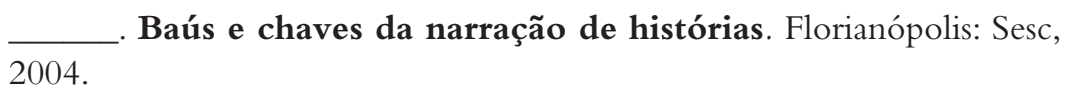
JUNQUEIRA, Guerra. Prefácio à segunda edição. A Velhice do Padre Eterno. Disponível em: < http://dc206.4shared.com/doc/erALGQtI/preview.html >. Acesso em: 27 maio 2012. 
KRISTEVA, Julia. Introdução à Semanálise. Trad. Lúcia Helena França Ferraz. São Paulo: Perspectiva, 1974.

LEMINSKI, Paulo. Ensaios Crípticos. Campinas: Unicamp, 1986.

LIBANIO, J. B. Qual o futuro do Cristianismo. 2. ed. São Paulo: Paulus, 2008.

MEIER, JOHN P. Um judeu marginal. São Paulo: Imago, 1993, Volume I.

MILES, Jack. Deus - uma Biografia. Trad. José Rubens Siqueira. São Paulo: Companhia das Letras, 1997.

MINOIS, Georges. História do Riso e do Escárnio. Trad. Maria Helena Ortiz Assumpção. São Paulo: Unesp, 2003.

RUSHDIE, Salman. Haroun e o Mar de Histórias. São Paulo: Companhia das Letras, 2008.

VIELHAUER, Philipp. História da Literatura Cristã Primitiva. Trad. Ilson Kayser. São Paulo: Academia Cristã Ltda., 2005.

\section{Imagens}

Fig. 1. A Velhice do Padre Eterno I. Disponível em: <http:// multimedia.fnac.pt/multimedia/PT/images_produits/PT/ ZoomPE/7/8/1/5601072511187.jpg?201012152021>. Acesso em: 31 maio 2012.

Fig. 2. A Velhice do Padre Eterno II. Disponível em: <http://4.bp.blogspot.com/-1vypjEtbHog/TZHgTBF14aI/AAAAAAAAAh8/v-js8TUpofl/ s1600/lealdacamara.jpg >. Acesso em: 31 maio 2012.

Fig. 3. Dez Mandamentos. Disponível em: <http://t3.gstatic.com/ images?q=tbn:ANd9GcSEAR4GE6gsFhWO8ifK8n375fWkni-TspoZdjg2M7BC5xU_-VUJcw>. Acesso em: 31 maio 2012.

Fig. 4. Sermão da Montanha. Disponível em: <http://ts4.mm.bing.net/ images $/$ thumbnail. aspx?q $=4836073618539315 \mathrm{\& id}=8 \mathrm{fe} 18 \mathrm{efce} 569 \mathrm{~d} 55502 \mathrm{f} 4 \mathrm{c}-$ 47cf1df6f05>. Acesso em: 31 maio 2012. 
Fig. 5. A Paixão de Cristo, Mel Gibson (2004). Disponível em: <http:// ts3.mm.bing.net/images/thumbnail.aspx?q=5053386075340822\&id=9159a174c08777361864dd4d4903a4bb>. Acesso em: 31 maio 2012.

Fig. 6. O Diabo. Disponível em: <http://3.bp.blogspot.com/_fFZOnbqkoAU/Ski8CzE138I/AAAAAAAAA0o/TzNd_7xEZa8/s320/images.jpg>. Acesso em: 31 maio 2012.

Fig. 7. Jorge Luis Borges e sua biblioteca. Disponível em: <http://1.bp.blogspot.com/-qkuNut56p-s/Tty2eXaiZUI/ AAAAAAAAH04/46SFxRfc23A/s1600/jorge-luis-borges.jpg >. Acesso em: 31 maio 2012.

Fig. 8. The Satanic Bible. Disponível em: <http://ts4.mm.bing. net/images $/$ thumbnail.aspx?q $=4882098478383643 \& \mathrm{id}=$ cb3dbc782d48663c8b7e9697ea67c637>. Acesso em: 31 maio 2012.

Fig. 9. Ao Mestre com carinho. Disponível em: <http://ts2.mm.bing.net/ images $/$ thumbnail.aspx?q $=4878744121903905 \& \mathrm{id}=$ f6e7f69ebed32ff214ab074abb6d9ae8>. Acesso em: 31 maio 2012. 